\title{
MANAJEMEN PERPUSTAKAAN SEKOLAH PADA SDN MAWAR VI BANJARMASIN
}

\author{
Rika Novyanti ${ }^{1}$ Fitriani $^{2}$, Padli $^{3}$, Sari Heppy Maharani ${ }^{4}$ \\ Politeknik Negeri Banjarmasin ${ }^{1,2,3,4}$, \\ ovy_green@yahoo.com ${ }^{1}$ \\ fitrianidahrani@gmail.com ${ }^{2}$
}

\begin{abstract}
Library is one of facilities needed in education system, it can be sourcse of learning process in teaching learning activities.The objectives of this community activity is to find out whether management of library's book storage in SDN Mawar VI Banjarmasin has been done based on the proper system. The activity is done by giving counseling and training toward teachers as the librarians. It is expected that this counseling and training could help the teachers to manage the library in order to increase students' interest to read. Another main objective is that this community activity can create a better teaching learning strategy.
\end{abstract}

Key words : Management, School library.

\begin{abstract}
ABSTRAK
Perpustakaan merupakan salah satu sarana yang paling dibutuhkan didalam pembangunan dunia pendidikan sebagai sumber belajar yang diperlukan dalam kegiatan belajar mengajar. Tujuan kegiatan pengabdian kepada masyarakat ini adalah untuk mengetahui apakah pengelolaan penyimpanan buku perpustakaan sesuai dengan kaidah kearsipan yang baku. Kegiatan pengabdian masyarakat ini dilaksanakan dengan memberikan penyuluhan dan pelatihan di lingkungan sekolah SDN Mawar VI Banjarmasin, melalui pelatihan manajemen perpustakaan sekolah diharapkan dapat memudahkan pengelola perpustakaan dalam mengelola perpustakaan, serta meningkatkan minat baca siswa. Hasil dari kegiatan pengabdian masyarakat ini diharapkan dapat meningkatkan mutu pendidikan bersama-sama dengan unsur sekolah lainnya. Sedangkan tujuan lainnya, adalah menunjang, mendukung, dan melengkapi semua kegiatan baik kurikuler, dan ekstra kurikuler, disamping dimaksudkan pula dapat membantu menumbuhkan minat dan mengembangkan bakat murid serta memantapkan strategi belalajar mengajar yang lebih baik lagi.
\end{abstract}

Kata Kunci : manajemen, perpustakaan sekolah

\section{PENDAHULUAN}

Perpustakaan sekolah dewasa ini merupakan salah satu komponen dalam sistem penbelajaran nasional. Perpustakaan harus dapat menjadi salah satu alternatif pusat kegiatan belajar mengajar dan pusat membaca untuk menambah ilmu pengetahuan serta rekreasi. Perpustakaan sekolah diharapkan tidak hanya menyediakan buku bacaan saja tetapi juga perlu menyediakan sumber informasi 
lainnya seperti, bahan audiovisual dan multimedia, serta akses informasi ke internet. Di dalam proses belajar mengajar buku memiliki peran yang sangat penting karena buku merupakan salah satu sumber informasi. Untuk mempermudah para pengguna perpustakaan dalam mencari buku yang diinginkan, maka diperlukan pengelolaan perpustakaan yang baik serta pelayanan yang memuaskan. Manajemen dalam perpustakaan sekolah bukan sekedar kegiatan menempatkan buku-buku di rak, akan tetapi lebih dari itu, sangat kompleks, berkelanjutan dan selalu berubah . Jadi ,manajemen merupakan sebuah proses yang memfokuskan pada memperhatikan kegiatan dari hari ke hari, menghadapi permasalahan isi dan integrasi dengan tujuan-tujuan sekolah. Sedangkan manjemen perpustakaan sekolah berhubungan dengan pengelolaan pengolahan data buku dan penyimpanan buku perpustakaan di sekolah. Banyak sekolah yang belum menyelenggarakan perpustakaan. Perpustakaan sekolah yang ada kebanyakan belum menyelenggarakan layanan secara baik, sehiongga dinilai masih kurang membantu proses belajar mengajar dan sering berfungsi sebagai tempat penyimpanan buku belaka. Hal tersebut dikarenakan beberapa alasan, seperti ada sejumlah kecil perpustakaan sekolah yang kondisinya cukup baik, tetapi belum terintegrasi dengan kegiatan belajar mengajar. Alasan lain adalah keberadaan dan kegiatan perpustakaan sekolah sangat tergantung dari sikap kepala sekolah sebagai pemegang kebijakan dalam segala hal. Yang paling penting dari kurangnya pengelolaan perpustakaan sekolah adalah kebanyakan sekolah tidak memiliki pustakawan (tenaga pengelola tetap), sering hanya dikelola oleh seorang guru yang setiap saat dapat dimutasikan. Oleh karena itulah tujuan dari kegiatan pengabdian kepada masyarakat ini adalah untuk mengetahui apakah pengelolaan penyimpanan buku perpustakaan telah sesuai dengan kaidah kearsipan yang baku di SDN Mawar VI Banjarmasin.

\section{METODE KEGIATAN}

Kegiatan pengabdian masyarakat ini dilaksanakan di lingkungan sekolah SDN Mawar VI jln. Kebun Sayur Banjarmasin, melalui pelatihan manajemen perpustakaan sekolah diharapkan dapat memudahkan pengelola perpustakaan dalam mengelola perpustakaan, serta meningkatkan minat baca para siswa. Kegiatan yang diberikan kepada peserta dalah dalam bentuk penyuluhan dan pelatihan. Penyuluhan diberikan dalam bentuk pemberian pemahaman tentang pentingnya pengelolaan manajemen perpustakaan sekolah yang baik, sedangkan pelatihan diberikan dalam bentuk praktik langsung pada $\mathrm{p}$ [roses pengelolaan inventaris perpustakaan. Adapun tolok ukur pencapaian keberhasilan pengabdian ini adalah terwujudnya para perpustakaan (guru-pustakawan) memiliki pengetahuan manajemen perpustakaan sekolah secara efektif dan mampu mendukung kurikulum dan program-program sekolah

\section{HASIL DAN PEMBAHASAN}

Perpustakaan sekolah pada saat ini bisa dikatakan "hidup segan, mati pun tak mampu", sebab jika kita lihat kondisinya seperti tidak terurus, artinya bahwa 
perpustakaan sekolah masih belum dikelola secara profesioanal. Bahkan banyak sekolah yang belum mempunyai perpustakaan padahal perpustakaan sangat diperlukan didalam suatu lembaga pendidikan tertentu.

Dari kondisi tersebut, sesungguhnya perpustakaan sekolah masih membutuhkan banyak bantuan dan dukungan dari berbagai pihak, baik dari lingkup internal maupun dari' luar sekolah. Dukungan dapat berupa material maupun yang bersifat immaterial. Kondisi perpustakaan yang memprihatinkan itu diperparah lagi dengan belum dikelolahnya dengan baik, ditambah minimnya petugas perpustakaan dimasing-masing sekolah yang profesional.

Secara umum, perpustakaan sekolah adalah sarana pendidikan yang turut menentukan pencapaian lembaga yang mcnaunginya. Oleh karena itu, perpustakaan sekolah adalah salah satu komponen yang turut menentukan tujuan yang telah ditetapkan.

Dari penjelasan para pakar tentang pengertian perpustakaan sekolah tersebut, dapat dipahami bahwa perpustakaan sekolah sesungguhnya adalah sarana penunjang pendidikan disekolah yang berupa kumpulan bahan pustaka baik berupa buku-buku maupun bukan buku. Kumpulan bahan pustaka tersebut diorganisasi secara sistematis dalam suatu ruang sehingga dapat membantu muridmurid dan para guru dalam proses pembelajaran. Sehingga dengan demikan, perpustakaan turut dalam menyukseskan pencapaian tujuan lembaga pendidikan yang menaunginya.

Penyelenggaraan perpustakaan sekolah mengacu kepada Undang-Undang Nomor 20 Tahun 2003 tentang sistem Pendidikan Nasional, terutama pada pasal 45. Pasal tersebul menyebutkan bahwa setiap satuan pendidikan formal dan nonformal menyediakan sarana dan prasarana yang memenuhi keperluan pendidikan sesuai dengan pertumbuhan dan perkembangan potensi fisik, kecerdasan. intelektual, sosial, emosional, dan kejiwaan peserta didik.

Hal tersebut diperkuat dengan dalam Peraturan Pemerintah No 19 Tahnn 2005 tentang Standar Nasional Pendidikan pada. pasal 42 dun 43 tentang standar sarana dan prasarana. Yang intinya menyebutkan bahwa sekolah wajib mcmiliki sarana salah satunya adalah buku dan sumber belajar. den wajib memiliki prasarana yakni perpustakaan.

Dalam praktiknya, kegiatan perpustakaan secara umum hampir serupa dengan kegiatan kearsipan. Khususnya dalam pengelolaan inventaris perpustakaan yang berupa buku, majalah, jurnal dan lain sebagainya. Sistem penyimpanan dan pengklasifikasian yang diterapkan perpustakaan secara umum adalah system subjek bernotasi, dengan ketentuan sebagai berikut:

Tabel 1. Klasifikasi Sistem Dewey pada Perpustakaan 


\begin{tabular}{|c|c|c|}
\hline Dewey \# & 10 Main Classes & Kinds of Books \\
\hline $000-099$ & General Works & $\begin{array}{l}\text { Encyclopedias, almanacs, record } \\
\text { books, swch as Guinness }\end{array}$ \\
\hline $100-199$ & Philosophy and Psychology & $\begin{array}{l}\text { paranormal phenomens such as } \\
\text { phosts, ethics now wre think }\end{array}$ \\
\hline $200-299$ & Religion & mythology, neligions \\
\hline $300-399$ & Social Science & $\begin{array}{l}\text { govermmom, holsdays, follkiore, faily } \\
\text { tales, education, communty }\end{array}$ \\
\hline $400-499$ & Language & $\begin{array}{l}\text { English and foreign langurages, sign } \\
\text { language, dictionaries }\end{array}$ \\
\hline $500-599$ & Natural Science & $\begin{array}{l}\text { mash, chemistsy, biology, weather, } \\
\text { rocks, plants, animals in noture }\end{array}$ \\
\hline $600-699$ & Applied Science & $\begin{array}{l}\text { inverntions, health, drugs: } \\
\text { transportation, cooking pets }\end{array}$ \\
\hline $700-799$ & Fine Arts and Recreation & $\begin{array}{l}\text { crafts an drawing painting music, } \\
\text { games. TV movies sports }\end{array}$ \\
\hline $800-899$ & Literature & 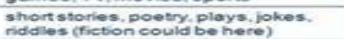 \\
\hline $900-999$ & History and Geography & $\begin{array}{l}\text { Countries. flags. Historical events. } \\
\text { biographios }(92 \text { or } 920)\end{array}$ \\
\hline
\end{tabular}

Sumber : martinrecords.com (2018)

Pada SDN Mawar VI Banjarmasin, karena perpustakaan yang dimilik masih berupa pojok baca yang diletakkan di setiap kelas, maka pengelolaan inventaris perpustakaan menjadi lebih sederhana lagi. Jika pada perpustakaan secara umum menggunakan system kearsipan subjek bernotasi seperti di atas, maka pada SDN Mawar VI dapat menggunakan pola system kearsipan Subjek murni, dengan pembagian subjek yang disesuaikan dengan koleksi buku yang ada di tiap kelas. Contohnya adalah sebagai berikut :

Tabel 2. Pengklasifikasian Sederhana Buku Perpustakaan Sekolah

\begin{tabular}{|c|c|c|c|c|}
\hline Klasifikasi & \multicolumn{2}{|c|}{ Kode } & \multicolumn{2}{|c|}{$\begin{array}{c}\text { Contoh klasifikasi berdasarkan } \\
\text { Jenis Buku }\end{array}$} \\
\hline Buku Cerita & $00-\mathrm{xxx}$ & - & $\begin{array}{l}\text { Kumpulan kisah Nusantara } \\
\text { (buku ke-1) }\end{array}$ & $00-001$ \\
\hline Buku Pelajaran & $11-\mathrm{xxx}$ & $\begin{array}{c}\text { Misal } \\
\text { Matematika } \\
\text { 11, Bahasa } \\
\text { Indonesia } \\
12, \text { dst }\end{array}$ & $\begin{array}{l}\text { Bahasa Indonesia (Buku ke- } \\
\text { 2) } \\
\text { Matematika (Buku ke-5) }\end{array}$ & $\begin{array}{l}12-002 \\
11-005\end{array}$ \\
\hline Pengetahuan Umum & 21-xxx & $\begin{array}{c}\text { Misal } \\
\text { ensiklopedia } \\
\text { 21, Kamus } \\
\text { Bahasa } \\
\text { Inggris 22 }\end{array}$ & $\begin{array}{l}\text { Ensiklopedia umum } \\
\text { Kamus Bahasa Inggris } \\
\text { (Buku ke-4) }\end{array}$ & $\begin{array}{l}21-000 \\
22-004\end{array}$ \\
\hline
\end{tabular}

Sumber : diolah (2018)

\section{Problem perpustakaan sekolah.}

Ada beberapa kondisi kurang baik atau permasalahan permasalahan yang dihadapi dalam pengolaan perpustakaan sekolah saat ini yakni:

1. Prioritas kebijakan dan pengambil kebijakan

2. Permasalahan lain yang sering menjadi hambatan bagi pengembangan perpustakan sekolah adalah tidak adanya SDM yang mengelola perpustakaan, atau minimnya tenaga perpustakaan.

3. Pemasalahan klasik yang selalu ditemui ketika penulis melakukan brain storming adalah ketidak tersediaan ruang/tempat atau minimnya tempat/ruang yang dipergunakan untuk perpustakaan

4. koleksi atau sumber daya koleksi merupakan 'nyawa' dari keberadaan perpustakaan sekolah. Koleksi perpustakaan merupakan bagian yang menjadi 'elemen' keberhasilan fungsi dan tujuan perpustakaan sekolah. 
Banyak kasus ditemui perpustakaan menjadi tidak 'laku' karena koleksinya yang sedikit, tidak lengkap dan kurang menarik

\section{KESIMPULAN}

Perpustakaan merupakan bagian integral dari' lembaga pendidikan sebagai tempat berkumpulnya bahan pustaka, baik berupa buku maupun non buku, dan tujuan utama penyelenggaraan perpustakaan sekolah adalah meningkatkan mutu pendidikan bersama-sama dengan unsur sekolah lainnya. Sedangkan tujuan lainnya, adalah menunjang, mendukung, dan melengkapi semua kegiatan baik kurikuler, dan ektra kurikuler, disamping dimaksudkan pula dapat membantu menumbuhkan minat dan mengembangkan bakat murid serta memantapkan strategi belalajar mengajar.

\section{DAFTAR PUSTAKA}

Bafadal, Ibraham. 2009. Pengelolahan Perpustakaan Sekolah. Jakarta: Bumi Aksara

Darmono. 2001. Manajemen Perpustakaan Sekolah. Jakarta Grasindo

Pusat Bahasa Depdiknas. 2008. Kamus Bessar Bahasa Indonesia. Jakarta: Gramedia.

Sinaga, Dina. 2011. Mengelola Perpustakaan Sekolah. Bandung: Bejana

NA. Desimal Dewey Klasifikasi Yang memudahkan Mencari Buku di Perpustakaan. 2018. http://www.martinrecords.com/technology/desimaldewey-klasifikasi-ddc-sistem-yang-memudahkan-mencari-buku-diperpustakaan/tanggal akses : 20 September 2018 